\title{
Temperature is a common climatic descriptor of lachryphagous activity period in Phortica variegata (Diptera: Drosophilidae) from multiple geographical locations
}

Marco Pombi ${ }^{*} \mathbb{D}$, Valentina Marino ${ }^{2}$, John Jaenike ${ }^{3}$, John Graham-Brown ${ }^{4}$, Ilaria Bernardini ${ }^{1}$, Riccardo P. Lia ${ }^{5}$, Fred Beugnet ${ }^{6}$, Guadalupe Miro ${ }^{2}$ and Domenico Otranto ${ }^{5}$

\begin{abstract}
Background: The drosophilid Phortica variegata is known as vector of Thelazia callipaeda, the oriental eyeworm native to Asia that has become an emergent zoonotic agent in several European regions. Unlike almost all other arthropod vectors of pathogens, only P. variegata males feed of lachrymal secretions of animals, ingesting first-stage larvae (L1) of the worm living in the orbital cavities of the host, and allowing with the same behaviour the introduction of infective L3. Despite the increased detection of T. callipaeda in many European countries, information about the length of the lachryphagous activity period of P. variegata and a deep knowledge of the environmental and climatic variables involved are still limited.
\end{abstract}

Methods: We herein present the results of a multicentre study involving five sites from four different countries (Italy, Spain, UK and USA) where canine thelaziosis is endemic and/or where it has already been ascertained the presence of P. variegata. Field data have been obtained on a fortnightly basis from mid-April to the end of November 2018 from a contemporary standardized sampling (same sampling effort and time of collection in all sites) of lachryphagous flies collected around the eyes of a human bait using an entomological net. These data have been associated to data collection of local climatic variables (day length, temperature, wind speed, barometric pressure and relative humidity).

Results: Overall, a total of 4862 P. variegata flies (4637 males and 224 females) were collected, with high differences in densities among the different sampling sites. Significant positive correlations were found between P. variegata male density and temperature and wind speed, while negative correlations were observed for barometric pressure and relative humidity. However, the above significant differences are confirmed in each sampling site separately only for the temperature.

Conclusions: This multicentre study highlights that temperature is the major common environmental driver in describing the lachryphagous activity of P. variegata in Europe and USA and, therefore, the transmission risk of thelaziosis.

Keywords: Eyeworm, Lachryphagy, Vector ecology, Vector-borne disease, Zoonosis, Environmental parameters

*Correspondence: marco.pombi@uniroma1.it

1 Dipartimento di Sanità Pubblica e Malattie Infettive, Sapienza Università di Roma, Rome, Italy

Full list of author information is available at the end of the article

(c) The Author(s) 2020. This article is licensed under a Creative Commons Attribution 4.0 International License, which permits use, sharing, adaptation, distribution and reproduction in any medium or format, as long as you give appropriate credit to the original author(s) and the source, provide a link to the Creative Commons licence, and indicate if changes were made. The images or other third party material in this article are included in the article's Creative Commons licence, unless indicated otherwise in a credit line to the material. If material is not included in the article's Creative Commons licence and your intended use is not permitted by statutory regulation or exceeds the permitted use, you will need to obtain permission directly from the copyright holder. To view a copy of this licence, visit http://creativeco mmons.org/licenses/by/4.0/. The Creative Commons Public Domain Dedication waiver (http://creativecommons.org/publicdomain/ zero/1.0/) applies to the data made available in this article, unless otherwise stated in a credit line to the data. 


\section{Background}

Phortica variegata (Diptera: Drosophilidae), a zoophilic fruit fly of the subfamily Steganinae (Drosophilidae), has attracted the interest of the scientific community because of its capacity to vector Thelazia callipaeda (Spirurida: Thelaziidae) eyeworms. Amongst vectorborne helminths, T. callipaeda is an emergent zoonotic agent of concern to the public health of several European regions. The adult nematodes live in the orbital cavities and associated host tissues of dogs, cats, foxes, wolves, rabbits and humans, causing ocular disease [1-3]. Unlike almost all other arthropod vectors of pathogens, only $P$. variegata males feed of lachrymal secretions of animals, ingesting first-stage larvae (L1) of the worm. According to data from experimental infestation $[4,5]$, in the vector the larval development through to infective L3 occurs within 14-21 days; larvae may also survive in overwintering flies (for up to 6 months) before being transmitted to a receptive host [4]. Although T. callipaeda has not been reported from the USA, $P$. variegata has been found also in this country, and it has been demonstrated that flies collected in the USA can successfully transmit the parasite [5]. At the time when vector identity and biology were elucidated, the infection was known only in remote poor settings in southern Italy $[4,6,7]$. Nevertheless, ecological niche models predicted that large areas of Europe (including the UK) are suitable for the presence of $P$. variegata, thus highlighting the potential risk of $T$. callipaeda spreading to other European countries [8, 9]. Indeed, whilst $T$. callipaeda had exclusively been reported from easternmost countries until two decades ago, it has now been described in both animals and humans from Austria, Belgium, Bosnia and Herzegovina, Bulgaria, Croatia, France, Germany, Greece, Hungary, Italy, Portugal, Romania, Serbia, Slovakia, Spain, Switzerland and Turkey [9-12]. Thus, this parasite can be considered as an emergent vector-borne pathogen in Europe, and zoonotic infections have been diagnosed on several occasions. As an example, in Spain, the first autochthonous case of thelaziosis was reported in 2010 [13]; following further reported cases of canine thelaziosis in this country, certain geographical areas are now considered endemic for this infection [14, 15]. Despite the increased detection of T. callipaeda in many European countries, information about the length of the lachryphagous activity period of $P$. variegata and a deep knowledge of the environmental and climatic variables involved are still limited.

We herein present the results of a multicentre study involving five sites from four different countries (Italy, Spain, UK and USA) where canine thelaziosis is endemic and/or where it has already been ascertained the presence of $P$. variegata. Data obtained from a contemporary standardized field sampling over the whole reproductive season of the vector, associated with data collection of local climatic variables, elucidated the common environmental drivers of the population dynamics of $P$. variegata in Europe and North America. These results are of major importance in describing the climatic features associated to the abundance of lachryphagous males of $P$. variegata and, when put in the context of climate change, the epidemiological consequences of the transmission of T. callipaeda to the vertebrate hosts, highlighting the importance of thelaziosis among the zoonosis of public health relevance that should not be neglected.

\section{Methods}

A longitudinal sampling was performed on a fortnightly basis from the mid of April to the end of November 2018 in five areas of four different countries in which $P$. variegata presence was already recorded. Each sampling site is described below.

\section{Sampling sites}

Highland Park (Rochester, NY, USA, $43^{\circ} 07^{\prime} 59^{\prime \prime} \mathrm{N}$, $7^{\circ} 36^{\prime} 43^{\prime \prime} \mathrm{W}$; altitude $240 \mathrm{~m}$ a.s.l.). This $\sim 60$ ha park was established in 1888 within a low-density urban area whose total population is 208,000 . The park occurs on a glacial moraine with alfisol soil. The area occurs with the humid continental climate zone with substantial seasonal variation in temperature. The site within the park where flies were collected includes relatively steep-sided slopes and flatter areas between the slopes. Quercus rubra is the dominant tree species, with individuals up to $150 \mathrm{~cm}$ in diameter at breast height (dbh). Other trees at the site include Juglans nigra, Prunus serotina, Acer saccharum, Gymnocladus dioicus, Betula papyrifera and Tilia americana. There is little understory except at the margins of the wooded areas, where the shrubs Rubus allegheniensis and Cercis canadensis occur. Animals at the site include Odocoileus virginianus, Vulpes vulpes, Sciurus carolinensis, Tamias striatus and Marmota monax.

New Forest (Hampshire district, England, UK, $50^{\circ} 50^{\prime} 32^{\prime \prime} \mathrm{N}, 01^{\circ} 30^{\prime} 53^{\prime \prime} \mathrm{W}$; altitude $20 \mathrm{~m}$ a.s.l.), a 219 square miles national park located on the south coast of mainland England. The climate is typical of the UK generally, with a temperate seasonal pattern of cold to cool winters and mild to warm summers with moderate rainfall throughout the year. The park is composed of a mixture of deciduous forest, predominantly Quercus rubra with Fagus sylvatica and Betula pendula, pastures and healthlands grazed by horses, cattle and wild cervids (Capreolus capreolus and Dama dama). The park is also 
home to a number of other sylvatic species common to british woodland habitats, including Meles meles and Vulpes vulpes. The trapping site used for this study was on a boundary between woodland and heath at a location where $P$. variegata has been documented on several occasions previously [9].

El Escorial (Sierra de Guadarrama, Madrid, Spain, $40^{\circ} 36^{\prime} 10^{\prime \prime} \mathrm{N}, 04^{\circ} 07^{\prime} 22^{\prime \prime} \mathrm{W}$; altitude $946 \mathrm{~m}$ a.s.l.). "La Herrería" forest is an area of 499 ha located in the "Sierra de Guadarrama", at $2.5 \mathrm{~km}$ south of the urban center of the municipality of El Escorial (northwest Madrid Community). The climate and vegetation are typically Mediterranean. Thus, summers are hot and dry, and maximum rainfall is recorded in autumn and spring. The vegetation consists of a rich range of herbaceous and woody species such as Quercus pyrenaica, Ilex aquifolium, Betula celtiberica, Crataegus monogyna and Pinus brutia. Animals most represented are Cervus elaphus, Sus scrofa, Capreolus capreolus, Dama dama, Meles meles, mustelids, Felis silvestris, Vulpes vulpes, Canis lupus and Lepus europaeus.

Manziana (Lazio region, Italy, $42^{\circ} 07^{\prime} 09^{\prime \prime} \mathrm{N}, 12^{\circ} 06^{\prime} 58^{\prime \prime} \mathrm{E}$; altitude $378 \mathrm{~m}$ a.s.l.). This region is a slightly hilly forested area of 545 ha of volcanic origin with poor Mediterranean climatic characteristics. The dominant tree species is Quercus cerris, which is mostly associated with Quercus frainetto. The dominant shrub species is Mespilus germanica, associated with Carpinus betulus, Acer monspessulanum, Acer campestre, Ilex aquifolium, Fraxinus ornus, Sorbus torminalis, Ruscus aculeatus, Ulmus minor, Malus sylvestris, Crataegus monogyna. The most abundant wild animal species are Vulpes vulpes, Sciurus vulgaris, Martes foina, Sus scrofa, Hystrix cristata, Lepus europaeus. The forest is surrounded by a hurbanized area (7700 inhabitants) and is also frequented by domestic species such as dogs, horses and cattle.

Oliveto Lucano (Basilicata region, Italy, $40^{\circ} 32^{\prime} 37^{\prime \prime} \mathrm{N}$, $16^{\circ} 09^{\prime} 18^{\prime \prime} \mathrm{E}$; altitude $900 \mathrm{~m}$ a.s.l.). The Park of Gallipoli Cognato covers an area of 27.027 ha within the borders of the towns of Accettura, Calciano and Oliveto Lucano in the province of Matera, and Castelmezzano and Pietrapertosa in the province of Potenza. In the all municipalities of the park live 4900 inhabitants. It is a mountain area of arenaceous rock, with peaks above $1000 \mathrm{~m}$ a.s.l. (e.g. mount Caperrino $1400 \mathrm{~m}$ a.s.l.). The presence of watercourses is conspicuous but in the form of seasonal torrents. In the forest the tree species are Quercus cerris, Quercus petraea, Quercus pubescens and Quercus frainetto. Moreover, Carpinus betulus, Tilia cordata, Acer campestre, Acer monospessullanum, Sorbus domestica and Fraxinus angustifolia are present. The shrub layer is mainly composed of Rubus fruticosus, Erica arborea, Genista tinctoria, Prumus spinosa, Amelanchier ovalis,
Crataegus monogyna, Sambucus nigra, and Ilex aquifolium. Wild animal species present are: Vulpes vulpes, Martes foina, Martes martes, Mustela nivalis, Erinaceus europaeus, Hystrix cristata, Lepus europeaeus, Lepus corsicanus, Sus scrofa, Sciurus vulgaris, Canis lupis and Felis silvestris. The forest is also frequented by domestic species such dogs, cats, sheep, pigs and cattle.

\section{Collection of lachryphagous flies}

In each sampling area two sites $200-400 \mathrm{~m}$ far from each other were chosen, to take into account for the local variability in the fly distribution. The sampling effort was 30 min per site, which was carried out twice in each sampling day (11:00-12:00 $\mathrm{h}$ and 15:00-16:00 h). Lachryphagous flies were collected around the eyes of a human bait using an entomological net, brought to the laboratory, and morphologically identified under a stereomicroscope [16].

\section{Analysis of $P$. variegata abundance}

Phortica variegata abundance obtained in each site was corrected, taking into account the effective sampling time as well as the number of collectors and baits used in each sampling (due to the occasional participation of two collectors at the same time). The daily abundance of lachryphagous males and females was transformed as $\log _{10}(x+1)$ of flies per person per hour in order to linearize the relationship with climatic variables. These values were then independently associated to the following climatic variables, collected daily from each site (Additional file 1: Table S1): day length (expressed as \% light time in $24 \mathrm{~h}$ ), temperature (mean, minimum, maximum, expressed as ${ }^{\circ} \mathrm{C}$ ), relative humidity (expressed as $\%$ ), barometric pressure (expressed as mbar), mean wind speed (expressed as $\mathrm{m} / \mathrm{s}$ ) in order to detect possible correlations. Relationships between fly densities and climatic variables were calculated by Kendall's tau-b rank correlations as a non-parametric measure adjusted for tied ranks using Statsdirect software version 3.2.8 [17].

\section{Results}

Overall, a total of 4862 P. variegata flies (4637 males and 224 females) were collected, with high differences in densities among the different sampling sites (Table 1). In particular, the largest collection was obtained from the sites at the lowest latitude, El Escorial (Spain), with 2387 P. variegata flies, followed by Manziana (Italy, $n=1204$ ), Oliveto Lucano (Italy, $n=1127$ ), Highland Park (USA, $n=135$ ) and New Forest (England, $n=9$ ). Data on mean fly densities corrected for the sampling effort (expressed as number of flies per person per hour; Table 1, Fig. 1) showed a similar picture: El Escorial (141.3); Manziana (141.6); Oliveto Lucano (75.1); Highland Park (9.0); and 


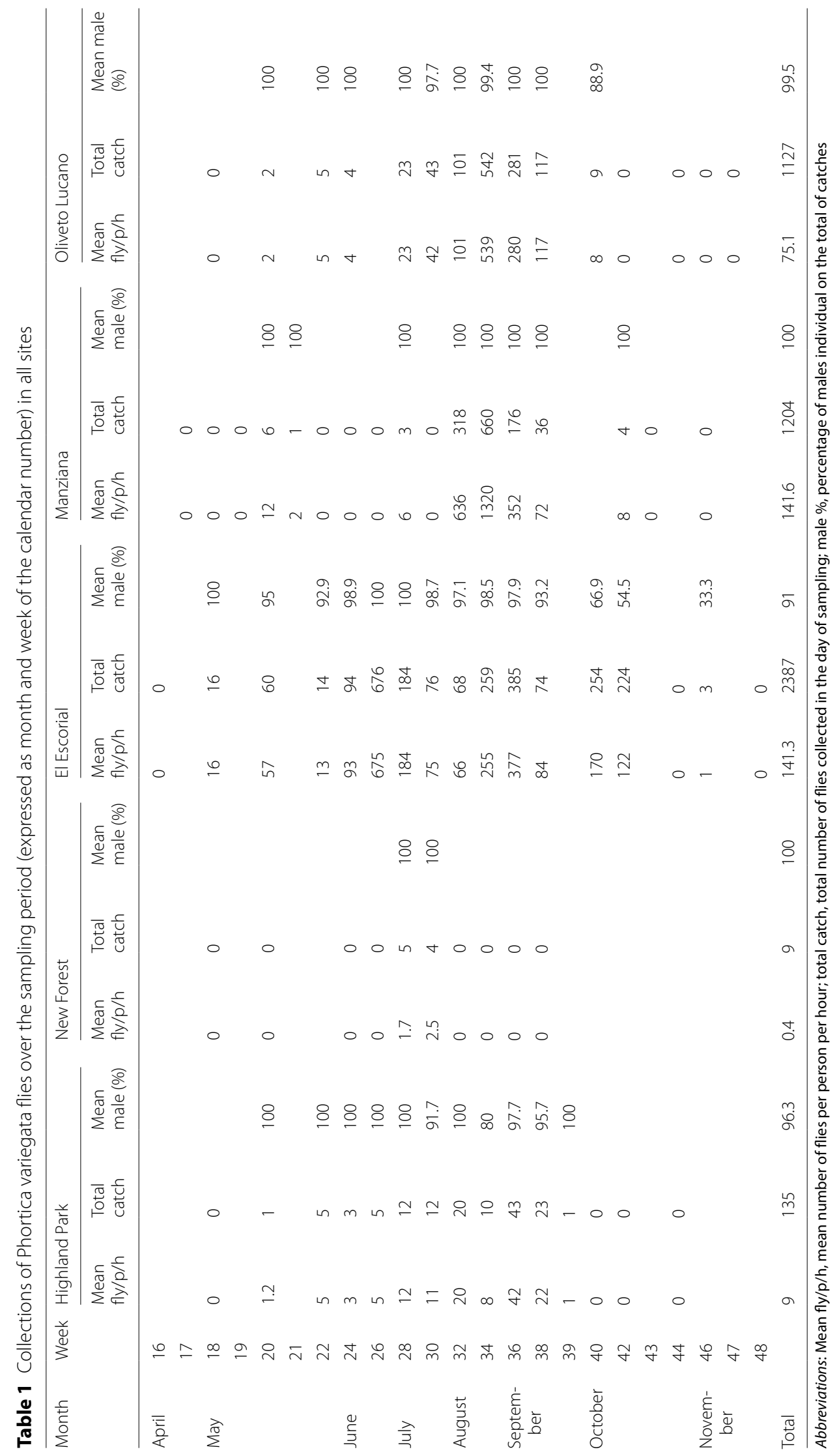




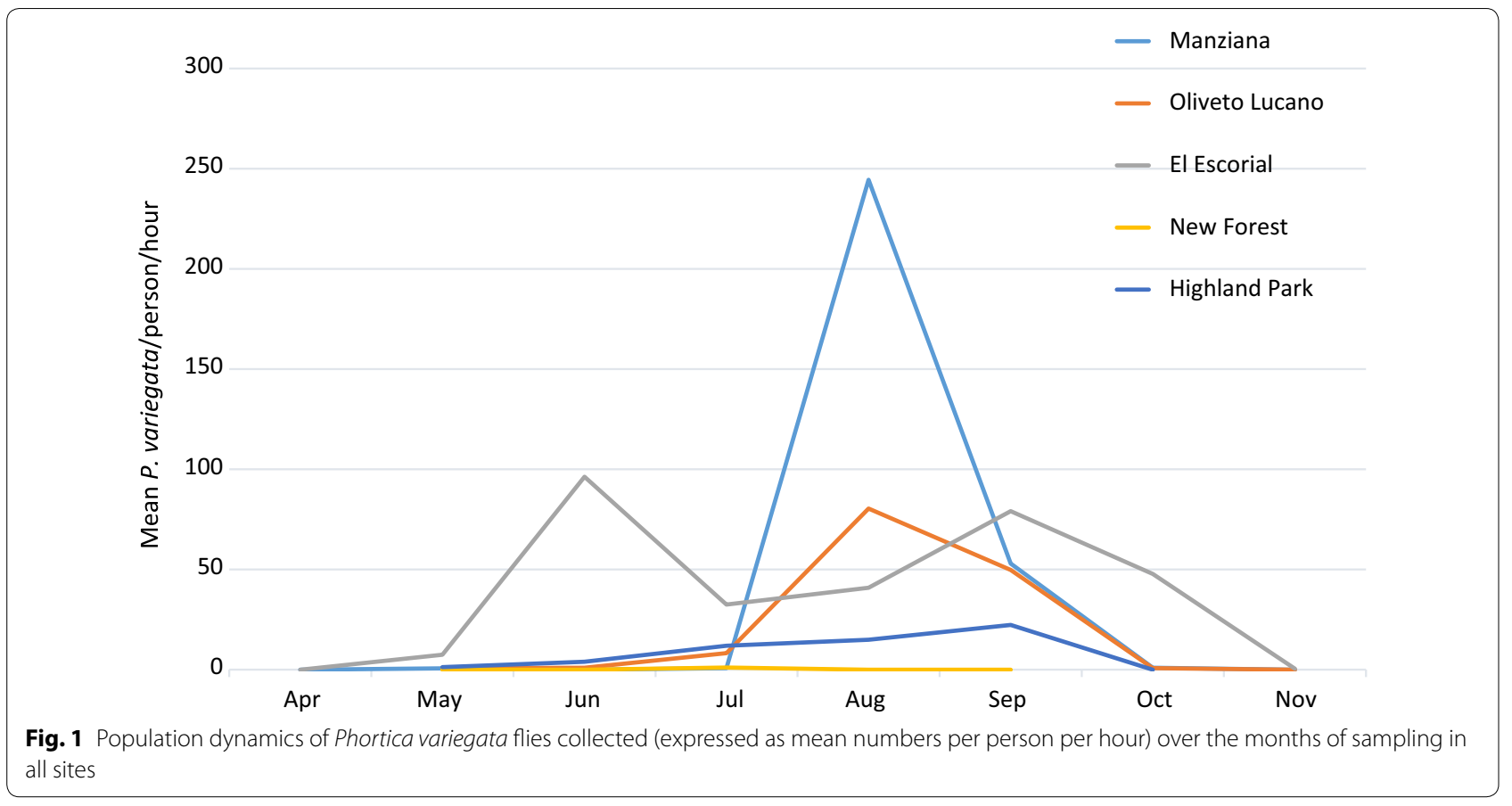

New Forest (0.4). Population dynamics of $P$. variegata in the different sites showed a unimodal curve with a common peak in density during weeks 34-36 (corresponding to the sampling dates 22nd August to 7th September 2018) in all sites but El Escorial. In the latter, a multimodal distribution has been observed, showing at least 4 peaks (weeks 20, 26, 36 and 40) with a maximum at week 26.

The male/female ratio obtained from the collection around the eyes of the human bait was heterogeneous (Table 1, Fig. 2), with sites in which only males were collected (Manziana and New Forest), and others in which some females were also trapped: El Escorial 9\%; Highland Park 3.7\%; and Oliveto Lucano 0.5\%. This supposed lachryphagous activity of females seems to be present all over the sampling season, without a specific pattern. However, a strong increase in female collection $(>30 \%)$ was observed from October in El Escorial.

Pooling data from all sites of the four countries, P. variegata male densities, expressed as the logarithm of flies per person per hour, showed significant positive correlations with temperature (maximum, minimum and mean) and mean daily wind speed, while negative correlations were observed for barometric pressure and relative humidity. However, the above significant differences are confirmed in each sampling site separately only for the temperature parameters (Table 2), with the exception of New Forest, in which no significant correlations were found. The other correlations observed in the single sites excluding the temperature were a negative correlation with wind speed in Manziana and with relative humidity in El Escorial.

The temperature of activity of lachryphagous males (in which at least one fly was collected) varies in different sites, ranging from a daily minimum of $7{ }^{\circ} \mathrm{C}$ (Manziana) to a daily maximum of $35{ }^{\circ} \mathrm{C}$ (El Escorial), despite the temperature range during the sampling period in all sites varied from $0{ }^{\circ} \mathrm{C}$ to $36^{\circ} \mathrm{C}$ (Table 3).

The correlation analysis of female densities of $P$. variegata (expressed as logarithm of flies per person per hour), cumulatively collected in the sites of Oliveto Lucano, El Escorial and Highland park, shows significant positive correlation with wind speed (Kendall's tau $b=0.24$; $P=0.043$ ) and negative correlations with pressure (Kendall's tau $b=-0.38 ; P=0.0008)$ and relative humidity (Kendall's tau $b=-0.29 ; P=0.010$ ).

\section{Discussion}

Our data indicate that temperature is an important driver of the seasonal dynamics of $P$. variegata lachryphagous males in the countries sampled, indicating that this climatic variable in particular is directly associated with the lachryphagous behaviour and therefore with the T. callipaeda transmission risk.

Vector-borne diseases follow complex epidemiological patterns due to the interaction of the pathogen, the vector and the vertebrate host/s species $[18,19]$. In the case of thelaziosis, the records of infected dogs, as well as other hosts including humans, are increasing in the past decade in several European countries, indicating that $T$. 


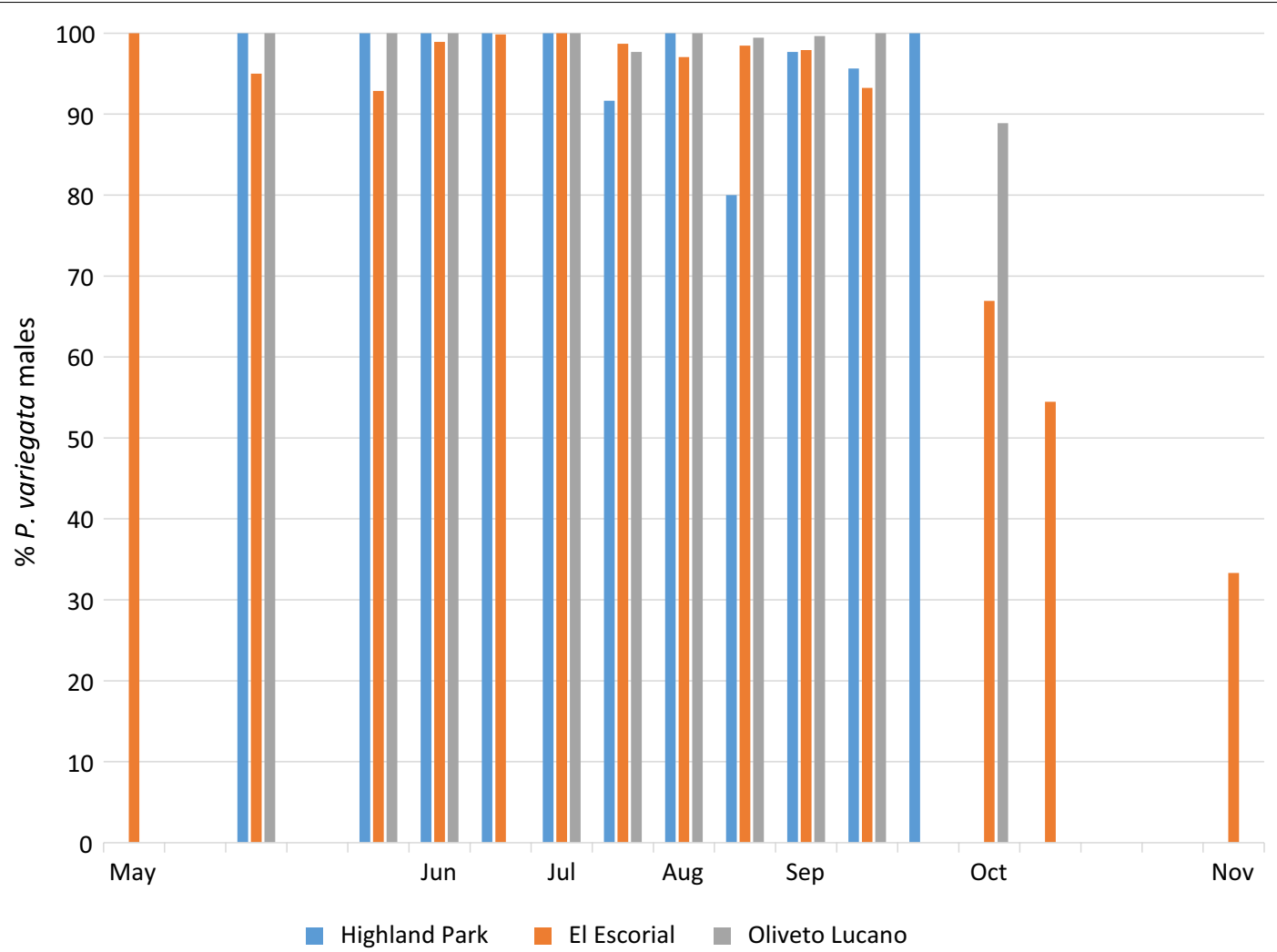

Fig. 2 Percentage of Phortica variegata males collected overall weeks of sampling (in numbers). Only the sites in which female presence have been observed were here considered

callipaeda is spreading continent-wide. This is probably due to the diffusion of the vector $P$. variegata or, more likely, to the movements of infected dogs in areas where the vector is present. The latter hypothesis is the most likely considering the nearly ubiquitous distribution of Phortica spp. flies [16]. The knowledge of the ecological niche of $P$. variegata is of major importance to understand if and how eyeworm infection can spread locally in different contexts, and what are the environmental drivers potentially favouring the establishment of the vector at a continental scale. A habitat suitability map of this species has been established, indicating a large potential of diffusion in Europe [8, 9]. However, data at the origin of the development of the model are fragmentary and, more importantly, no information is available concerning environmental parameters affecting the population dynamics of $P$. variegata, except those obtained from a few sites $[8,14]$. The multicentre approach herein presented allows identification of the climatic parameters that correlate with the population dynamics of $P$. variegata across the reproductive season.

Among the five sites of the four countries sampled, $P$. variegata has shown to be mostly present in Spain and South Italy (Table 1), as already described for the sites El
Escorial [14] and Oliveto Lucano [7, 20], as well as in a site of Central Italy where $P$. variegata has been described here for the first time (i.e. Manziana). The latter is a forest in which Turkey oak tree (Quercus cerris) is highly abundant, confirming the strong ecological associations between P. variegata and this species [8, 9]. At higher latitudes (New Forest, UK) and in the only site out of Europe (Highland Park, USA), P. variegata showed a narrow period of activity (Fig. 1), which might be explained by the less permissive climatic conditions observed in these sites compared to the localities in Spain and Italy (Additional file 1: Table S1). At this site in North America, the dominant tree species is the northern red oak (Quercus rubra), suggesting that association between oaks and the distribution of $P$. variegata may be quite general.

The present results show a direct correlation among temperature measures in the whole dataset, as well as analysing the different sites separately (Table 2 ), indicating that this parameter is important in the lachryphagous activity of $P$. variegata males. On the contrary, the direct correlation with mean wind speed, as well as the inverse correlation with barometric pressure and relative humidity, showed significant values only including data from all sites. But, when analysed per site, they seem to have a 
Table 2 Kendall's rank correlation of climatic variables versus Phortica variegata males referred to the day of sampling

\begin{tabular}{|c|c|c|c|c|}
\hline Site & Variable & Valid $n$ & Kendall's tau b & $P$-value \\
\hline \multirow[t]{7}{*}{ All sites } & Day length & 76 & 0.021 & 0.80 \\
\hline & $\begin{array}{l}\text { Maximum tempera- } \\
\text { ture }\end{array}$ & 75 & 0.45 & $<0.0001$ \\
\hline & $\begin{array}{l}\text { Minimum tempera- } \\
\text { ture }\end{array}$ & 75 & 0.40 & $<0.0001$ \\
\hline & Mean temperature & 75 & 0.43 & $<0.0001$ \\
\hline & Mean wind speed & 73 & 0.17 & 0.044 \\
\hline & Barometric pressure & 76 & -0.25 & 0.003 \\
\hline & Relative humidity $^{\mathrm{a}}$ & 55 & -0.23 & 0.014 \\
\hline \multirow[t]{7}{*}{ Manziana } & Day length & 17 & -0.16 & 0.44 \\
\hline & $\begin{array}{l}\text { Maximum tempera- } \\
\text { ture }\end{array}$ & 16 & 0.30 & 0.15 \\
\hline & $\begin{array}{l}\text { Minimum tempera- } \\
\text { ture }\end{array}$ & 16 & 0.15 & 0.025 \\
\hline & Mean temperature & 16 & 0.34 & 0.10 \\
\hline & Mean wind speed & 17 & -0.40 & 0.039 \\
\hline & Barometric pressure & 17 & 0.13 & 0.53 \\
\hline & Relative humidity & 7 & 0.59 & 0.10 \\
\hline \multirow[t]{7}{*}{ Oliveto Lucano } & Day length & 17 & 0.27 & 0.16 \\
\hline & $\begin{array}{l}\text { Maximum tempera- } \\
\text { ture }\end{array}$ & 17 & 0.58 & 0.002 \\
\hline & $\begin{array}{l}\text { Minimum tempera- } \\
\text { ture }\end{array}$ & 17 & 0.39 & 0.041 \\
\hline & Mean temperature & 17 & 0.47 & 0.015 \\
\hline & Mean wind speed & 17 & -0.15 & 0.44 \\
\hline & Barometric pressure & 17 & -0.08 & 0.70 \\
\hline & Relative humidity & 17 & -0.07 & 0.74 \\
\hline \multirow[t]{7}{*}{ El Escorial } & Day length & 17 & 0.30 & 0.10 \\
\hline & $\begin{array}{l}\text { Maximum tempera- } \\
\text { ture }\end{array}$ & 17 & 0.57 & 0.002 \\
\hline & $\begin{array}{l}\text { Minimum tempera- } \\
\text { ture }\end{array}$ & 17 & 0.48 & 0.008 \\
\hline & Mean temperature & 17 & 0.59 & 0.001 \\
\hline & Mean wind speed & 14 & -0.16 & 0.47 \\
\hline & Barometric pressure & 17 & 0.35 & 0.057 \\
\hline & Relative humidity & 16 & -0.39 & 0.042 \\
\hline \multirow[t]{7}{*}{ New Forest } & Day length & 10 & 0.18 & 0.60 \\
\hline & $\begin{array}{l}\text { Maximum tempera- } \\
\text { ture }\end{array}$ & 10 & 0.55 & 0.07 \\
\hline & $\begin{array}{l}\text { Minimum tempera- } \\
\text { ture }\end{array}$ & 10 & 0.22 & 0.51 \\
\hline & Mean temperature & 10 & 0.44 & 0.15 \\
\hline & Mean wind speed & 10 & -0.11 & 0.80 \\
\hline & Barometric pressure & 10 & -0.11 & 0.80 \\
\hline & Relative humidity & na & na & na \\
\hline
\end{tabular}

different relationship according to the geographical context. In fact, wind and relative humidity are negatively correlated with the lachryphagous dynamics of $P$. variegata males only in Manziana and El Escorial, respectively, indicating that their effect is probably linked to local
Table 2 (continued)

\begin{tabular}{lllll}
\hline Site & Variable & Valid $n$ & Kendall's tau b & P-value \\
\hline Highland Park & Day length & 15 & 0.24 & 0.25 \\
& $\begin{array}{l}\text { Maximum tempera- } \\
\text { ture }\end{array}$ & 15 & 0.56 & 0.006 \\
$\begin{array}{l}\text { Minimum tempera- } \\
\text { ture }\end{array}$ & 15 & 0.76 & 0.0002 \\
$\begin{array}{l}\text { Mean temperature } \\
\text { Mean wind speed }\end{array}$ & 15 & 0.52 & 0.010 \\
& 15 & 0.06 & 0.80 \\
Barometric pressure & 15 & -0.18 & 0.39 \\
Relative humidity & 15 & 0.08 & 0.73 \\
\hline
\end{tabular}

a New Forest data not available

Notes: Day length recorded as \% of light in 24 hours; temperature recorded as ${ }^{\circ} \mathrm{C}$ wind speed recorded as $\mathrm{m} / \mathrm{s}$; pressure recorded as $\mathrm{hPa}$; humidity recorded as $\%$. Italic highlights the variables with significant correlations $(P$-value $<0.05)$

Abbreviations: Valid $\mathrm{n}$, records used in the statistics; Kendall's tau b, correlation value; $P$-value, two-sided significance level of the $b$-statistics; na, data not available

Table 3 Temperature $\left({ }^{\circ} \mathrm{C}\right.$ ) ranges (minimum-maximum) for which at least one male individual of Phortica variegata was collected and the temperature range measured over the sampling period in each site of the study

\begin{tabular}{llll}
\hline Site & $\operatorname{Min} . \mathrm{T}\left({ }^{\circ} \mathrm{C}\right)$ & $\operatorname{MaxT}\left({ }^{\circ} \mathrm{C}\right)$ & $\begin{array}{l}\text { Temperature } \\
\text { range }\left({ }^{\circ} \mathrm{C}\right)\end{array}$ \\
\hline Highland Park & 9 & 34 & $0-34$ \\
New Forest & 11 & 29 & $1-29$ \\
El Escorial & 8 & 35 & $3-35$ \\
Manziana & 7 & 34 & $5-36$ \\
Oliveto Lucano & 9 & 32 & $9-32$ \\
\hline
\end{tabular}

situations and it should not be excluded that they are spurious correlations.

The few $P$. variegata females captured around human eyes in three sites out of five (i.e. Oliveto Lucano, El Escorial and Highland Park) showed correlations with day length, relative humidity and barometric pressure but not with temperature. However, even if we take this observation as anecdotal and of negligible epidemiological relevance (considering the low numbers of females collected in this study), it seems that the environmental drivers associated with females are different from those linked to males.

\section{Conclusions}

The heterogeneity of statistical associations of climatic parameters and the different sampling points taken into account in this multicentre study indicates how complex is the population dynamics of $P$. variegata concerning 
its geographical distribution. Temperature is a common descriptor of $P$. variegata male lachryphagy in almost all sites (with exception of the northern area, i.e. New Forest, UK, in which however the small dataset did not allow to obtain reliable results) both at its extreme values (minimum and maximum). By sampling across a wide range of temperatures, ranging from $0{ }^{\circ} \mathrm{C}$ to $36^{\circ} \mathrm{C}$ (Table 3), we were able to ascertain that the minimum temperature in which lachryphagous activity occurred ranged from $7{ }^{\circ} \mathrm{C}$ to $11{ }^{\circ} \mathrm{C}$, regardless the latitude. If we put these results in the frame of the global climate changing scenario, we can suppose that the future increase in temperatures predicted from IPCC [21] will subsequently modify (possibly increasing) the period of activity of $P$. variegata as well as its distribution and density northwards Europe [9] and, possibly, North America. The epidemiological consequences of these results reside in the direct relationship between lachryphagous activity of $P$. variegata males and the transmission of $T$. callipaeda to the vertebrate hosts, increasing the relevance of thelaziosis in the public health that should not be neglected.

\section{Supplementary information}

Supplementary information accompanies this paper at https://doi. org/10.1186/s13071-020-3955-0.

Additional file 1: Table S1. Monthly values of the climatic variables measured in this study per each sampled site during the period of activity of Phortica variegata.

\section{Abbreviations}

a.s.l.: above sea level; dbh: diameter at breast height.

\section{Acknowledgements}

Sample collection at the New Forest site, UK, was gratefully assisted by Jennifer Palfreyman, University of Liverpool, and conducted in collaboration with the medical entomology group, Public Health England.

\section{Authors' contributions}

MP and DO conceived the study. MP, VM, GM and DO organized the sampling plan. MP, VM, JJ, JGB, IB and RPL collected data in the field and identified the specimens. MP analysed the results. MP and DO drafted the manuscript and all authors critically contributed to its final version. All authors read and approved the final manuscript.

\section{Funding}

The sampling activity in Manziana (Rome) was supported by ClinGlobal \& Boehringer-Ingelheim.

\section{Availability of data and materials}

The datasets used and analysed during the present study are available from the corresponding author on reasonable request.

Ethics approval and consent to participate Not applicable.

\section{Consent for publication}

Not applicable.

\section{Competing interests}

The authors declare that they have no competing interests.

\section{Author details}

${ }^{1}$ Dipartimento di Sanità Pubblica e Malattie Infettive, Sapienza Università di Roma, Rome, Italy. ${ }^{2}$ Animal Health Department, Veterinary Faculty, Universidad Complutense de Madrid, Madrid, Spain. ${ }^{3}$ University of Rochester, Rochester, NY, USA. ${ }^{4}$ Department of Livestock Health and Welfare, Institute of Veterinary Science, University of Liverpool, Liverpool, UK. ${ }^{5}$ Dipartimento di Medicina Veterinaria, Università degli Studi di Bari "Aldo Moro", Bari, Italy.

${ }^{6}$ Boehringer Ingelheim Animal Health, Lyon, France.

Received: 4 November 2019 Accepted: 10 February 2020

Published online: 18 February 2020

\section{References}

1. Shen J, Gasser RB, Chu D, Wang Z, Yuan X, Cantacessi C, et al. Human thelaziosis - a neglected parasitic disease of the eye. J Parasitol. 2006;92:872-5

2. Otranto D, Dantas-Torres F, Brianti E, Traversa D, Petrić D, Genchi C, et al. Vector-borne helminths of dogs and humans in Europe. Parasites Vectors. 2013;6:16.

3. Malacrida F, Hegglin D, Bacciarini L, Otranto D, Nägeli F, Nägeli C, et al. Emergence of canine ocular thelaziosis caused by Thelazia callipaeda in southern Switzerland. Vet Parasitol. 2008;157:321-7.

4. Otranto D, Cantacessi C, Testini G, Lia RP. Phortica variegata as an intermediate host of Thelazia callipaeda under natural conditions: evidence for pathogen transmission by a male arthropod vector. Int J Parasitol. 2006:36:1167-73

5. Otranto D, latta R, Lia RP, Cavalera MA, Máca J, Pombi M, et al. Competence of Phortica variegata from the United States as an intermediate host of the Thelazia callipaeda eyeworm. Am J Trop Med Hyg. 2018:98:1175-8.

6. Otranto D, Ferroglio E, Lia RP, Traversa D, Rossi L. Current status and epidemiological observation of Thelazia callipaeda (Spirurida, Thelaziidae) in dogs, cats and foxes in Italy: a "coincidence" or a parasitic disease of the Old Continent? Vet Parasitol. 2003;116:315-25.

7. Otranto D, Lia RP, Buono V, Traversa D, Giangaspero A. Biology of Thelazia callipaeda (Spirurida, Thelaziidae) eyeworms in naturally infected definitive hosts. Parasitology. 2004;129:627-33.

8. Otranto D, Brianti E, Cantacessi C, Lia RP, Máca J. The zoophilic fruitfly Phortica variegata: morphology, ecology and biological niche. Med Vet Entomol. 2006;20:358-64.

9. Palfreyman J, Graham-Brown J, Caminade C, Gilmore P, Otranto D, Williams DJL. Predicting the distribution of Phortica variegata and potential for Thelazia callipaeda transmission in Europe and the United Kingdom. Parasites Vectors. 2018;11:272.

10. Timmins DR, Staunton KM, Meyer DB, Townsend M, Paton CJ, Ramírez AL, et al. Modifying the biogents sentinel trap to increase the longevity of captured Aedes aegypti. J Med Entomol. 2018;55:1638-41.

11. Ionică AM, Deak G, D'Amico G, Stan GF, Chișamera GB, Constantinescu IC, et al. Thelazia callipaeda in mustelids from Romania with the European badger, Meles meles, as a new host for this parasite. Parasites Vectors. 2019;12:370.

12. Hodžić A, Payer A, Duscher GG. The first autochthonous case of feline ocular thelaziosis in Austria. Parasitol Res. 2019;118:1321-4.

13. Miró G, Montoya A, Hernández L, Dado D, Vázquez M, Benito M, et al. Thelazia callipaeda: infection in dogs: a new parasite for Spain. Parasites Vectors. 2011:4:148.

14. Marino V, Gálvez R, Colella V, Sarquis J, Checa R, Montoya A, et al. Detection of Thelazia callipaeda in Phortica variegata and spread of canine thelaziosis to new areas in Spain. Parasites Vectors. 2018;11:195.

15. Fuentes I, Montes I, Saugar JM, Latrofa S, Gárate T, Otranto D. Thelaziosis in humans, a zoonotic infection, Spain, 2011. Emerg Infect Dis. 2012;18:2073-5. 
16. Bachli G, Vilela C, Escher SA, Saura A. The Drosophilidae (Diptera) of Fennoscandia and Denmark. Fauna Entomologica Scandinavica, Vol. 39 Leiden: Brill; 2005

17. StatsDirect Ltd. StatsDirect statistical software. Cheshire: StatsDirect Ltd 2013.

18. Otranto D. Arthropod-borne pathogens of dogs and cats: from pathways and times of transmission to disease control. Vet Parasitol. 2018;251:68-77.

19. Matthews KR. Controlling and coordinating development in vectortransmitted parasites. Science. 2011;331:1149-53.

20. Otranto D, Dantas-Torres F, Mallia E, DiGeronimo PM, Brianti E, Testini $\mathrm{G}$, et al. Thelazia callipaeda (Spirurida, Thelaziidae) in wild animals: report of new host species and ecological implications. Vet Parasitol. 2009;166:262-7.
21. Masson-Delmotte V, Zhai P, Pörtner HO, Roberts D, Skea J, Shukla PR et al. Global warming of $1.5^{\circ} \mathrm{C}$. An IPCC special report on the impacts of global warming of $1.5^{\circ} \mathrm{C}$ above pre-industrial levels and related global greenhouse gas emission pathways, in the context of strengthening the global response to the threat of climate change. 2018. https://www.ipcc. ch/sr15/. Accessed 6 Feb 2020.

\section{Publisher's Note}

Springer Nature remains neutral with regard to jurisdictional claims in published maps and institutional affiliations.
Ready to submit your research? Choose BMC and benefit from:

- fast, convenient online submission

- thorough peer review by experienced researchers in your field

- rapid publication on acceptance

- support for research data, including large and complex data types

- gold Open Access which fosters wider collaboration and increased citations

- maximum visibility for your research: over $100 \mathrm{M}$ website views per year

At BMC, research is always in progress.

Learn more biomedcentral.com/submissions 